\title{
Sciendo
}

RESEARCH PAPERS FACULTY OF MATERIALS

SCIENCE AND TECHNOLOGY IN TRNAVA

SLOVAK UNIVERSITY OF TECHNOLOGY

IN BRATISLAVA

2019, Volume 27, Number 44

DOI 10.2478/rput-2019-0008

\section{SORPTION OF METHYLENE BLUE BY ALTERNATIVE ADSORBENTS}

\author{
Maroš SOLDÁN ${ }^{1}$, Hana KOBETIČOVÁ ${ }^{1}$, Tomáš ŠTEFKO ${ }^{1}$ \\ ${ }^{1}$ SLOVAK UNIVERSITY OF TECHNOLOGY IN BRATISLAVA, \\ FACULTY OF MATERIALS SCIENCE AND TECHNOLOGY IN TRNAVA, \\ INSTITUTE OF INTEGRATED SAFETY, \\ Ulica JÁNA BotTu 2781/25, 91724 TRNAVA, SLOVAK REPUBLIC \\ e-mail:maros.soldan@stuba.sk, hana.kobeticova@stuba.sk, tomas.stefko@stuba.sk \\ Received: 02.05.2019, Accepted: 26.06.2019, Published: 25.07.2019
}

\begin{abstract}
The presence of dyes in effluents is a major concern due to their adverse effects to many forms of life. Dyes are generally removed by conventional sorbents. This article discusses the use of adsorbents from the waste metal production (low-cost sorbents), red mud (RM) and black nickel mud (BNM), to remove methylene blue solution (MB) under different test conditions, such as time and temperature of sorption and weight of sorbent samples. From the obtained data, we can claim that the highest achieved sorption efficiency was achieved by a RM sorbent at $60{ }^{\circ} \mathrm{C}$ after 48 hours of sorption with all three weights of samples $(83.01-83.72 \%)$.
\end{abstract}

Key words

Red mud, black nickel mud, sorption efficiency

\section{INTRODUCTION}

Many industrial processes use a variety of synthetic chemical dyes for various uses. The industries like paper and pulp manufacturing, dyeing of cloth, textiles, leather treatment, printing, food products etc. used dyes and the effluents released from these industries bear large amounts of coloured wastes. It has been estimated that about 800,000 tons of synthetic dyes are produced annually and $\sim 50 \%$ of these are azo dyes) [1].

It is estimated that approximately $15 \%$ of the dye stuffs are lost in industrial effluents during manufacturing and processing operations [2].

Dyes exhibit a complex aromatic molecular structure and are generally resistant to light, temperature and oxidizers. These characteristic features make the dye non-degradable, causing bioaccumulation in living organisms and leading to severe diseases and disorders.

Methylene blue (MB) is a cationic dye having various applications in chemistry, biology, medical science and dyeing industries. MB is the most commonly used substance for dying 
cotton, wood and silk. It can cause eye burns which may be responsible for permanent injury to the eyes of human and animals. On inhalation, it can give rise to short periods of rapid or difficult breathing while ingestion through the mouth produces a burning sensation and may cause nausea, vomiting, profuse sweating, mental confusion and methemoglobinemia [3].

Nowadays, great attention has been focused on elimination of the effluents bearing dyes, owing to their potential toxicity and visibility problems.

Colour is conventionally removed by chemical precipitation and biological oxidation. However, these processes are not always effective and economical where the solute concentrations are very low. Moreover, most of the synthetic organic dyes undergo a very slow biodegradation. Currently the sorption technique is proved to be an effective and attractive process for the treatment of the dye containing wastewater [2].

Recently, numerous approaches have been studied for the development of cheaper and effective adsorbents. Many non-conventional low-cost adsorbents, including natural materials, biosorbents, and waste materials from agriculture and industry, have been proposed by several researchers. These materials could be used as adsorbents for the removal of dyes from solution.

Many treatment processes have been applied for the removal of dyes from wastewater such as: photocatalytic degradation [4, 5], sonochemical degradation [6], micellar enhanced ultrafiltration [7], cation exchange membranes [8], electrochemical degradation [9], adsorption/precipitation processes [10], integrated chemical-biological degradation [11], integrated iron(III) photo assisted-biological treatment [12], solar photo-Fenton and biological processes [13], Fenton-biological treatment scheme [14] and adsorption on activated carbon. $[15,16]$ As synthetic dyes in wastewater cannot be efficiently decolorized by traditional methods, their adsorption on inexpensive and efficient solid supports was considered as a simple and economical method for their removal from water and wastewater [17].

Adsorption has been found to be superior to other techniques for water re-use in terms of initial cost, flexibility and simplicity of design, ease of operation and insensitivity to toxic pollutants [3].

\section{MATERIALS AND METHODOLOGY OF EXPERIMENT}

In the experiment described in this article, we applied sorption to remove MB using lowcost sorbents - red mud (RM) and black nickel mud (BNM).

Red mud is obtained from the $\mathrm{Al}_{2} \mathrm{O}_{3}$ production by the Bayer method, in which the bauxite is leached with sodium hydroxide under high pressure and temperature. Dissolved sodium aluminate is precipitated and calcined after cleaning in the next steps [18].

Red mud is a stable mixture of chemical compounds and a subject with a stable structure of a known and typical chemical composition [19]. In Slovakia, aluminium oxide was produced mainly by sintering in the aluminium mill in Žiar nad Hronom from 1957 to 1997 [20, 21]. The studied sample of the red mud sorbent came from the above-mentioned ash pond.

Black nickel mud represents the waste from the nickel and cobalt production process from the imported Albanian iron-nickel lateritic ore containing $1 \%$ nickel. It is a fine material with a fraction mostly below $0.01 \mathrm{~mm}[22,23]$.

Soldánová et al. (2009) state that the black nickel mud with a chromium and nickel residue is a substantially iron concentrate of a chemical composition [24].

Black nickel mud, which was used for the research purposes came from the waste landfill in Sered'. The Albanian iron-nickel ore has been processed in Niklová huta, š.p., Sered' since 1963 [22, 23]. This landfill lies at $125 \mathrm{~m}$ a.s.l. on the southern edge of Dolnovážska niva on the intersection of the cadastral areas of Sered' and Dolná Streda [22].

Pre-adjustment of the samples of red mud and black nickel mud was proposed to remove possible organic impurities that could have negative effect on sorption capacity of the sorbents. 
Sorbents were annealed in a muffle furnace, VEB ELECTRO Bad Frankenhausen LM 312.11 at $600{ }^{\circ} \mathrm{C}$ for four hours, followed by cooling in a desiccator. Requested fraction of the samples $(<500 \mu \mathrm{m})$ was obtained by sieve analysis.

In the experimental part, the efficiency of the sorption of the 3,5-dichlorophenol with the sorbents and the influence of the sorption conditions (Table 1) were observed. Homogenisation of the solution was performed by a HEIDOLPH Promax 1020 shaker, at a rate of $160 \mathrm{~T} \mathrm{~min}^{-1}$. Tested samples were stirred throughout the whole time of sorption. During investigating the effect of temperature (using the MEMMERT 100-800 dryer) on sorption, the shaker was not used, and the homogenisation of the solution was performed manually. Subsequently, the samples were, at specified time, placed in a JANETZKI T30 centrifuge for 10 minutes, at a rotational speed of $2000-3000 \mathrm{~g}$ to sediment the small, undesirable, particles of sorbent. The loss of MB was determined by spectrophotometer GENESYS 8 in UV/VIS area $(500-800$ $\mathrm{nm}$ ). The highest light absorbance (amount of light absorbed by the material) of MB is at 670 $\mathrm{nm}$. The achieved value of absorbance (at $665 \mathrm{~nm}$ ) was used to calculate the efficiency of absorbents according to (1):

$$
\eta_{\mathrm{t}}=\frac{A_{0}-A_{t}}{A_{0}} \times 100[\%],
$$

where: $\eta t$-sorption efficiency,

$\mathrm{A}_{0}$ - detector response of MB sample concentration,

$\mathrm{A}_{\mathrm{t}}-$ detector response after sorption.

Table 1 Test condition of chosen low-cost sorbents in the process of MB sorption (author)

\begin{tabular}{|c|c|c|}
\hline Sorbent weight $(\mathrm{g})$ & Temperature $\left({ }^{\circ} \mathrm{C}\right)$ & Time $(\mathrm{h})$ \\
\hline $\mathbf{0 . 2}$ & $\mathbf{2 5}$ & $\mathbf{1}$ \\
\hline $\mathbf{0 . 4}$ & $\mathbf{4 0}$ & $\mathbf{2}$ \\
\hline $\mathbf{0 . 6}$ & $\mathbf{6 0}$ & $\mathbf{3}$ \\
\hline & & $\mathbf{2 4}$ \\
\hline
\end{tabular}

\section{RESULTS AND DISCUSSION ON RESULTS}

In Figure 1, we can see the sorbent efficiency of Red mud (RM) a Black nickel mud (BNM) at $25{ }^{\circ} \mathrm{C}$, with three different weights of sorbent. The sorption efficiency of RM and BNM achieved in the first three hours of sorption was $0 \%$ and $0.32-4.32 \%$ respectively. At the sorption time of 24 and 48 hours, the RM sorbent achieved a relatively low sorbent efficiency, at the range of $0.43-4.67 \%$. Higher sorption efficiency was achieved by BNM $(0.6 \mathrm{~g})$ after 24 hours (19.31\%) and after 48 hours (34.62\%). 


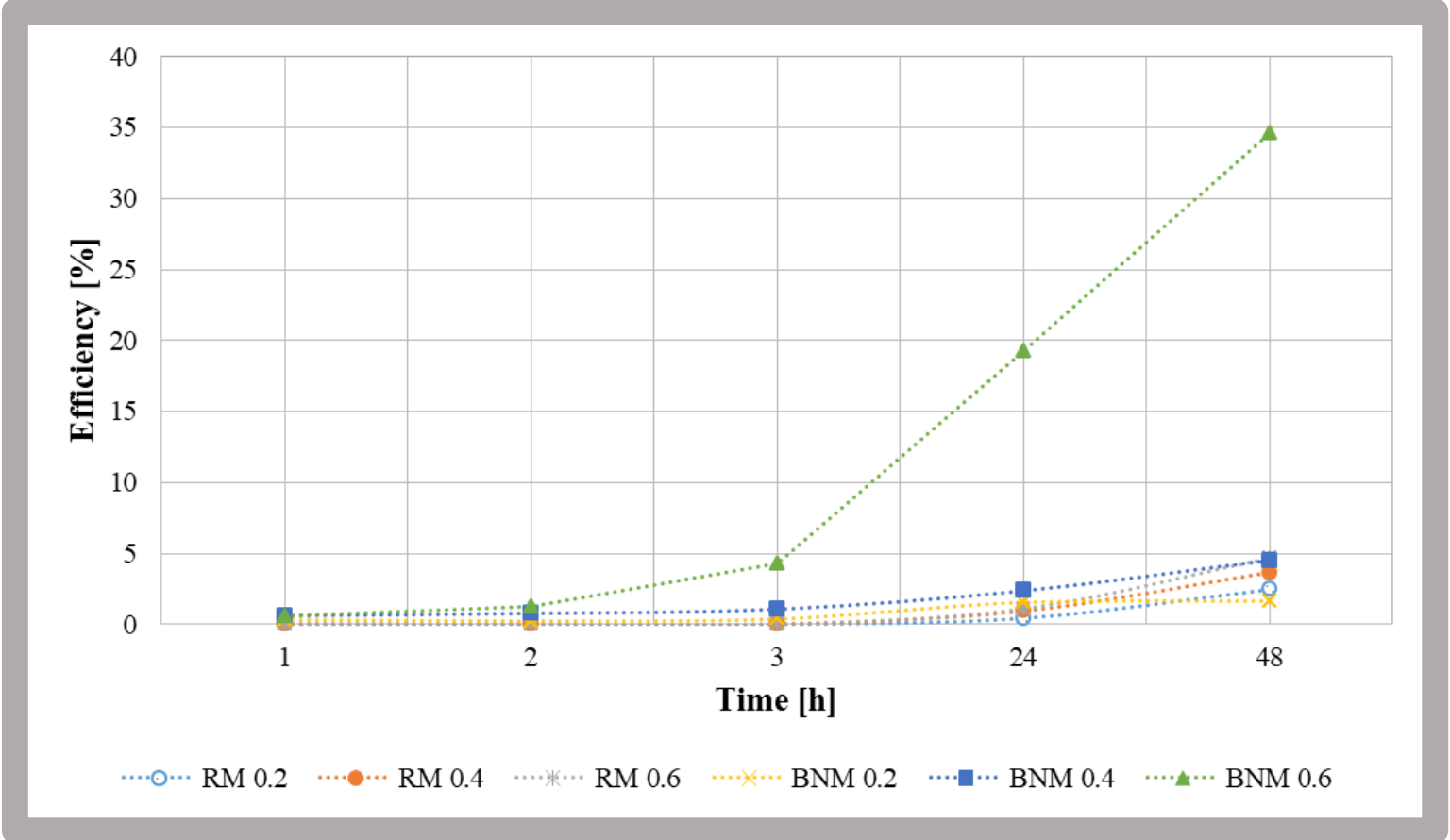

Fig. 1 Sorbent efficiency at $25^{\circ} \mathrm{C}$

Although no sorption occurred during the first three hours of sorption at $40{ }^{\circ} \mathrm{C}$ in any of the tested sorbents, the long-term sorbent efficiency was higher compared to the previous measurement, as shown in Figure 2. The highest sorption efficiency of BNM achieved at $0.6 \mathrm{~g}$ after 48 hours $\left(40.28 \%\right.$ ) was slightly higher than that at $25{ }^{\circ} \mathrm{C}$. Efficiency of RM was significantly improved at this temperature after 24 and 48 hours of sorption, and after 48 hours it reached $34.01 \%(0.2 \mathrm{~g}), 50.49 \%(0.4 \mathrm{~g})$ and $55.38 \%(0.6 \mathrm{~g})$.

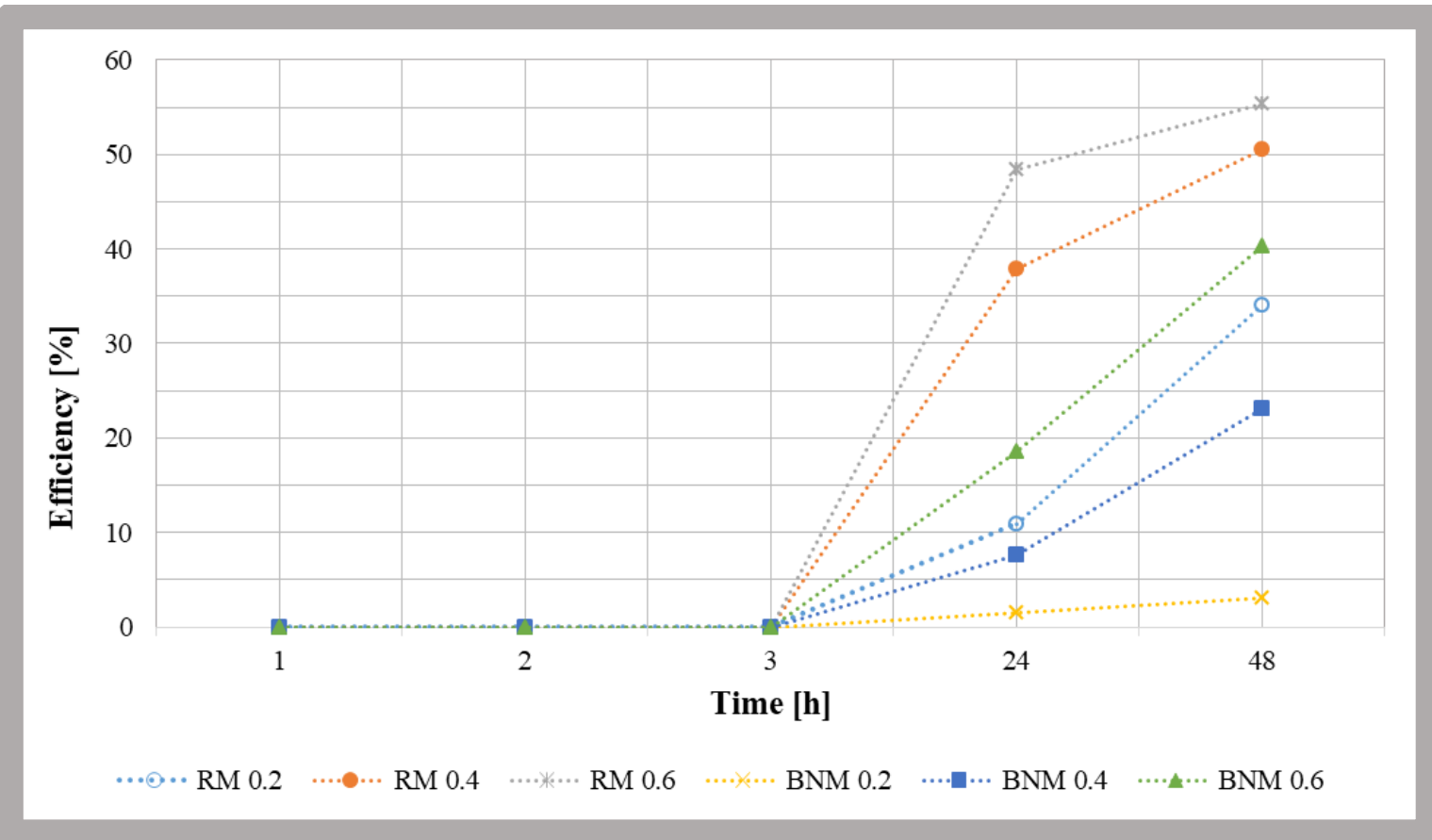

Fig. 2 Sorbent efficiency at $40{ }^{\circ} \mathrm{C}$ 
Sorption efficiency of selected sorbents at $60{ }^{\circ} \mathrm{C}$ is shown in Figure 3. As in previous measurements, sorption efficiency of all samples during the first three hours was zero. After 24 hours, sorption efficiency of all sorbents exceeded $60 \%$ (except $0.2 \mathrm{~g} \mathrm{BNM}$, which reached $27.17 \%$ ). Although the highest values were reached at 48 hours of sorption with RM sorbents $(83.01-83.72 \%)$, efficiency of these sorbents after 24 hours is negligibly lower $(80.28-80.9 \%)$, thus more effective in the economical way.

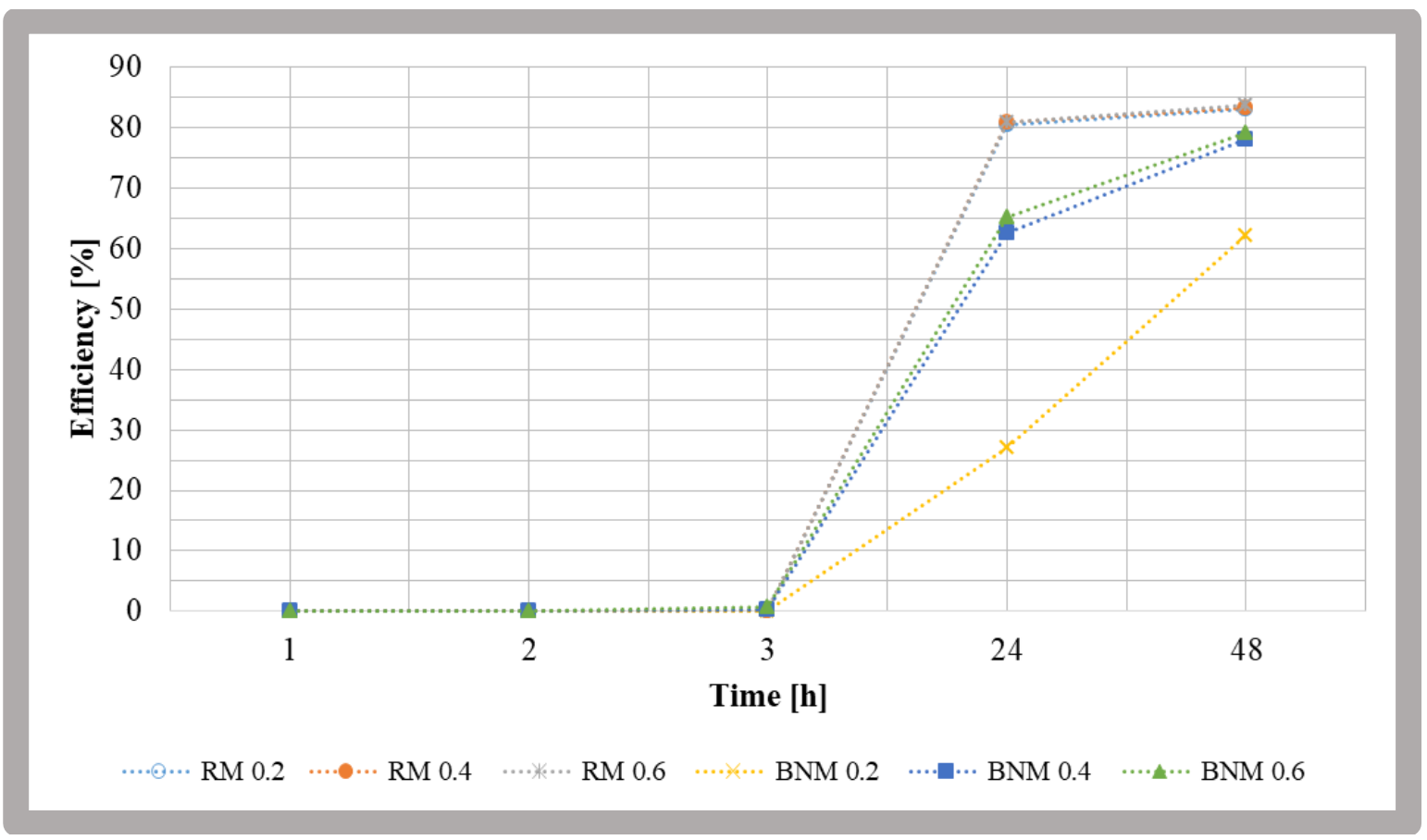

Fig. 3 Sorbent efficiency at $60^{\circ} \mathrm{C}$

\section{CONCLUSION}

Based on the results stated above, we can say that two of the tested parameters (time and temperature) have a significant impact on sorption efficiency. Time of the sorption is an important parameter as it influences the costs and simplicity of the operation. Our findings suggest that the sorption time should be at least 24 hours, as no (or negligible) sorption occurred in the first three hours of the sorption. After 24 hours, the sorption effectivity increased in both cases.

Temperature of the operation also has a positive influence on the sorption efficiency. The highest values of efficiency were achieved at $60{ }^{\circ} \mathrm{C}$, particularly $80.28-83.72 \%$. Weight of the sample has lower impact on the overall sorption efficiency.

From the two tested sorbents, red mud and black nickel mud, RM achieved higher sorption rates at increased temperature $\left(40,60^{\circ} \mathrm{C}\right)$. We can assume that it is due to different chemical composition, and higher adsorption-active oxide content. However, as low-cost sorbents, they both are effective for methylene blue dye sorption under right conditions.

\section{Acknowledgement}

This research output was supported by the Slovak Research and Development Agency under the contract No. APVV-16-0223.

This research output was supported by the Cultural and Education Agency of the Ministry of Education, Science, Research and Sport of the Slovak Republic (KEGA 030UMB-4/2017). 


\section{References}

[1] BANERJEE, S., CHATTOPADHYAYA, M.C. 2017. Adsorption characteristics for the removal of a toxic dye, tartrazine from aqueous solutions by a low cost agricultural by-product. Arabian Journal of Chemistry [online]. 10, S1629-S1638 [vid. 2019-04-30]. ISSN 1878-5352. Available at: doi:10.1016/J.ARABJC.2013.06.005

[2] PATHANIA, D., SHARMA, S., SINGH, P. 2017. Removal of methylene blue by adsorption onto activated carbon developed from Ficus carica bast. Arabian Journal of Chemistry [online]. 10, S1445-S1451 [vid. 2019-04-30]. ISSN 1878-5352. Available at: doi:10.1016/J.ARABJC.2013.04.021

[3] RAFATUllaH, M., SUlaimAN, O., HASHIM, R., AHMAD, A. 2010. Adsorption of methylene blue on low-cost adsorbents: A review. Journal of Hazardous Materials [online]. 177(1-3), 70-80 [vid. 2019-04-30]. ISSN 0304-3894. Available at: doi:10.1016/J.JHAZMAT.2009.12.047

[4] SleimAn, M., VILDOZO, D., FERRONATO, C., CHOVElON, J. M. 2007. Photocatalytic degradation of azo dye Metanil Yellow: Optimization and kinetic modeling using a chemometric approach. Applied Catalysis B: Environmental [online]. 77(1-2), 1-11 [vid. 2019-04-30]. ISSN 0926-3373. Available at: doi:10.1016/J.APCATB.2007.06.015

[5] SOHRABI, M.R., GHAVAMI, M. 2008. Photocatalytic degradation of Direct Red 23 dye using UV/TiO2: Effect of operational parameters. Journal of Hazardous Materials [online]. 153(3), 1235-1239 [vid. 2019-04-30]. ISSN 0304-3894. Available at: doi:10.1016/J.JHAZMAT.2007.09.114

[6] ABBASI, M., RAZZAGHI, N. 2008. ASL. Sonochemical degradation of Basic Blue 41 dye assisted by nanoTiO2 and H2O2. Journal of Hazardous Materials [online]. 153(3), 942-947 [vid. 2019-04-30]. ISSN 0304-3894. Available at: doi:10.1016/J.JHAZMAT.2007.09.045

[7] ZAGHBANI, N., HAFIANE, A., DHAHBI, M. 2008. Removal of Safranin T from wastewater using micellar enhanced ultrafiltration. Desalination [online]. 222(1-3), 348-356 [vid. 2019-0430]. ISSN 0011-9164. Available at: doi:10.1016/J.DESAL.2007.01.148

[8] WU, J. S., LIU, Ch. H., CHU, K. H., SUEN, S. Y. 2008. Removal of cationic dye methyl violet 2B from water by cation exchange membranes. Journal of Membrane Science [online]. 309(1-2), 239245 [vid. 2019-04-30]. ISSN 0376-7388. Available at: doi:10.1016/J.MEMSCI.2007.10.035

[9] FAN, L., ZHOU, Y., YANG, W., CHEN, G., YANG, F. 2008. Electrochemical degradation of aqueous solution of Amaranth azo dye on ACF under potentiostatic model. Dyes and Pigments [online]. 76(2), 440-446 [vid. 2019-04-30]. ISSN 0143-7208. Available at: doi:10.1016/J.DYEPIG.2006.09.013

[10] ZHU, M. X, LEE, L., WANG, H. H., WANG, Z. 2007. Removal of an anionic dye by adsorption/precipitation processes using alkaline white mud. Journal of Hazardous Materials [online]. 149(3), 735-741 [vid. 2019-04-30]. ISSN 0304-3894. Available at: doi:10.1016/J.JHAZMAT.2007.04.037

[11] SUDARJANTO, G., KELLER-LEHMANN, B., KELLER, J. 2006. Optimization of integrated chemical-biological degradation of a reactive azo dye using response surface methodology. Journal of Hazardous Materials [online]. 138(1), 160-168 [vid. 2019-04-30]. ISSN 0304-3894. Available at: doi:10.1016/J.JHAZMAT.2006.05.054

[12] SARRIA, V., DERONT, M., PÉRINGER, P., PULGARIN, C. 2003. Degradation of a biorecalcitrant dye precursor present in industrial wastewaters by a new integrated iron(III) photoassisted-biological treatment. Applied Catalysis B: Environmental [online]. 40(3), 231-246 [vid. 2019-04-30]. ISSN 0926-3373. Available at: doi:10.1016/S0926-3373(02)00162-5

[13] GARCÍA-MONTAÑO, J., PÉREZ-ESTRADA, L., OLLER, I., MALDONADO, M. I. 2008. Francesc TORRADES a José PERAL. Pilot plant scale reactive dyes degradation by solar photoFenton and biological processes. Journal of Photochemistry and Photobiology A: Chemistry [online]. 195(2-3), 205-214 [vid. 2019-04-30]. ISSN 1010-6030. Available at: doi:10.1016/J.JPHOTOCHEM.2007.10.004

[14] LODHA, B., CHAUDHARI, S. 2007. Optimization of Fenton-biological treatment scheme for the treatment of aqueous dye solutions. Journal of Hazardous Materials [online]. 148(1-2), 459-466 [vid. 2019-04-30]. ISSN 0304-3894. Available at: doi:10.1016/J.JHAZMAT.2007.02.061 
[15] HAMEED, B.H., DAUD, F.B.M. 2008. Adsorption studies of basic dye on activated carbon derived from agricultural waste: Hevea brasiliensis seed coat. Chemical Engineering Journal [online]. 139(1), 48-55 [vid. 2019-04-30]. ISSN 1385-8947. Available at: doi:10.1016/J.CEJ.2007.07.089

[16] WU, F. Ch., TSENG, R. L. 2008. High adsorption capacity $\mathrm{NaOH}$-activated carbon for dye removal from aqueous solution. Journal of Hazardous Materials [online]. 152(3), 1256-1267 [vid. 2019-04-30]. ISSN 0304-3894. Available at: doi:10.1016/J.JHAZMAT.2007.07.109

[17] FORGACS, E., CSERHÁTI, T., OROS, G. 2004. Removal of synthetic dyes from wastewaters: a review. Environment International [online]. 30(7), 953-971 [vid. 2019-04-30]. ISSN 0160-4120. Available at: doi:10.1016/J.ENVINT.2004.02.001

[18] HIND, A. R., BHARGAVA, S. K., GROCOTT, S. C. 1999. The surface chemistry of Bayer process solids: a review. Colloids and Surfaces A: Physicochemical and Engineering Aspects [online]. 146(1-3), 359-374 [vid. 2019-04-30]. ISSN 0927-7757. Available at: doi:10.1016/S09277757(98)00798-5

[19] SCHWARZ, M., LALÍK, V. 2011. Biologické účinky, vylúhovatel'nost' a testovanie ekotoxicity odpadového kalu z výroby oxidu hlinitého (Biological effects, leachability and tests of ecotoxicity of waste mud from aluminium oxide producction). Chemické Listy (Chemical letters), 105(7), 518523.

[20] KAFKA, R., ČAMBÁLOVÁ, L. 2001. Z dejín výroby hlinika na Slovensku (From the history of aluminium production in Slovakia). ISBN 978-80-88892-39-7.

[21] SCHWARZ, M., LALÍK, V., VANEK, M. 2001. Možnosti využitia odpadového kalu z výroby oxidu hlinitého (Options of utilising the waste mud from aluminium oxide production). Chemické Listy (Chemical letters),105(7), 114-121.

[22] MICHAELI, E. 2012. Skládka priemyselného odpadu lúženca ako príklad environmentálnej zát'aže pri bývalej Niklovej huti Sered' (The landfill of industrial waste of black nickle mud near the former Nickel Smelter in Sered' as an example of environmental burden). Životné prostredie, 62(2), 6368.

[23] MICHAELI, E., BOLTIŽIAR, M. 2010. Vybrané lokality environmentálnych zát'aží v Slovenskej republike (Selected localities of environmental burdens in the Slovak Republic). GEOGRAPHIA CASSOVIENSIS, 4(2), 114-119.

[24] SOLDÁNOVÁ, Z., SOLDÁN, M., ČAPLOVIČ, L. 2009. Štúdium kinetiky adsorpcie CrVI červeným kalom a lúžencom (Study of CrVI adsorption kinetics by the red mud and black nickle mud). Waste forum, 2, 58-65.

\section{ORCID}

Maroš Soldán 0000-0003-1520-1051 